Jurnal

Belo
Volume 6 Nomor 1 Agustus 2020 - Januari 2021

DOI: https://doi.org/10.30598/belovol6issue1page1-10

p-ISSN : 2460-6820 | e-ISSN : 2686-5920

Penerbit : Fakultas Hukum Universitas Pattimura

\title{
Sifat Melawan Hukum Materiil Dalam Perbuatan Pidana Penanganan Bencana Non-Alam Covid 19
}

Tresya ${ }^{1, *}$

${ }^{1}$ Fakultas Hukum Universitas Batanghari, Jambi tresyashmh@gmail.com ${ }^{1}$

* Corespondence Author

\begin{abstract}
Abstrak
Penanganan Coronavirus Disease diperlukan langka cepat karena laju pertambahan kasus harus dihentikan, namun dengan memperlambat penyebaran virus manusia harus dibatasi pergerakannya, pada sisilain akan timbul berbagai masalah lain, untuk itu pemerintah selain melakukan pembatasan, pemerintah juga megelontorkan uang untuk menangani efek domino dari penganan bencana. Disisi lain akan menimbulkan masalah dikemudian hari dengan dana yang digunakan oleh pemerintah dan komite stabilitas sitem keuangan Negara Indonesia. Tujuan penulisan ini untuk menemukan rumusan sifat melawan materiil dalam penangganan penyebaran virus dikaitkan dengan peraturan perundang-undangan. Metode yuridis normatif. Hakim dalam menjatuhkan putusan untuk kasus penangganan virus harus juga melihat sifat melawan hukum materiil walaupun sudah ada putusan mahkamah kostitisi tetang penghapusan melawan hukum materiil.
\end{abstract}

\section{Kata Kunci : Melawan Hukum Materiil, Coronavirus Disease, Perbuatan}

Naskah dikirim: 17 Juli 2020|Direvisi : 10 Agustus 2020|Diterbitkan: 21 Agustus 2020 


\begin{abstract}
Handling of Coronavirus Disease is needed to be rare fast because the rate of increase in cases must be stopped, but by slowing down the spread of the human virus its movement must be limited, on the other hand various other problems will arise, for this reason the government besides imposing restrictions, the government also spends money to deal with the domino effect of disaster relief. On the other hand, it will cause problems in the future with the funds used by the government and the Indonesian State financial system stability committee. The purpose of this paper is to find the formulation of material against materiality in preventing the spread of the virus in relation to statutory regulations. Normative juridical methods. Judges in ruling for cases of virus subscription must also see the nature of material against the law, even though there has been a decision by the constitutional court regarding elimination against material law.
\end{abstract}

\title{
Keywords: Against Material Law, Coronavirus Disease, Action
}

\section{Pendahuluan}

Corona virus merupakan keluarga besar virus yang menyebabkan penyakit ringan sampai berat, seperti common cold atau pilek dan penyakit yang serius seperti MERS dan SARS, Penularannya dari hewan ke manusia (zoonosis) dan penularan dari manusia ke manusia sangat terbatas. Sampel yang diteliti menunjukkan etiologi coronavirus baru. Awalnya, penyakit ini dinamakan sementara sebagai 2019 novel coronavirus (2019nCoV), kemudian WHO mengumumkan nama baru pada 11 Februari 2020 yaitu Coronavirus Disease (COVID-19) yang disebabkan oleh virus Severe Acute Respiratory Syndrome Coronavirus-2 (SARS-CoV-2). ${ }^{1}$

Jumlah negara yang telah terkonfirmasi terdapat Covid-19 adalah 216 Negara dengan jumlah pasien positif berjumlah 13.150.645 dengan korban meninggal mencapai

\footnotetext{
${ }^{1}$ Adityo Susilo dkk (2020), Coronavirus Disease 2019: Tinjauan Literatur Terkini, Jurnal Penyakit Dalam Indonesia, Volume. 7, Nomor. 1, Maret 2020, Universitas Indonesia, hal. 45

DOI: https://doi.org/10.30598/belovol6issue1page1-10 Copyright (c) 2020 Author
} 
574.464, Indonesia sendiri jumlah pasien positif 80.094, pasien sembuh 39.050, pasien meninggal

3.797. ${ }^{2}$ Pemerintah bergerak cepat dengan mengeluarkan beberapa peraturan untuk menangulanggi pandemik Covid-19, 13 Maret 2020 Persiden mengeluarkan Keputusan Presiden Nomor 7 Tahun 2020, 31 Maret 2020 Presiden kembali mengeluarkan Keputusan Presiden tentang Kedauratan Covid 19. Pada tanggal yang sama Presiden menerbitkan Peraturan Pemerintah Penganti Undang-Undang Nomor 1 Tahun 2020, yang kemudian pada tanggal 12 Mei 2020 disetujui menjadi Undang-Undang Nomor 2 Tahun 2020.

Undang-undang ini hadir untuk menghadapi ancaman efek domino dari penyebaran virus Covid-19 yang membahayakan Perekonomian Nasional dan/atau Stabilitas Sistem Keuangan Negara. Awalnya pemeritah mealokasi Rp 405,1 triliun, lalu naik menjadi Rp 677 triliun, Rp 695,2 triliun, Menteri Keuangan memprediksi dana penagganan covid-19 akan mencapai Rp 905,1 triliun, menggingat jumlah kasus covid-19 yang belum ada tren penurunan, dan kesenjangan ekonomi yang semakin meluas. Sri Mulayni mengatakan stimulus perekonomian harus diberikan untuk menjaga kita tidak ada dalam resesi perekonomian sehingga rakyat semakin sengsara. ${ }^{3}$

Penulis teringat kata Lord Action perna mengatakan "power tends to corrupts absolutely. ${ }^{4}$ Dana sebesar ini tentunya akan menimbulkan masalah hukum bila tidak dikelola secara baik. Undang-Undang Nomor 2 Tahun 2020 ini dimaksudkan untuk menjaga perekonomian Negara, namun terdapat pertentangan ancara juris-juris ilmu hukum tentang sifat melawan hukum yang hilang dalam Pasal 27 Undang-Undang Nomor 2 Tahun 2020. Permasalahan dalam tulisan ini adalah apakah sifat melawan hukum telah dihilangkan karena pasal 27 Undang-Undang Nomor 2 Tahun 2020. Tujuan penulisan ini untuk mengetahui sifat melawan hukum materiil dalam Undang-Undang

\footnotetext{
${ }^{2}$ Covid19.co.id diakses 16 Juli 2020

${ }^{3}$ https://www.cnnindonesia.com/ekonomi/20200619172653-532-515291/sri-mulyani-sebut-danapenanganan-corona-naik-jadi-rp905-t, diakses 16 Juli 2020

${ }^{4}$ Ermansjah Djajah, Tipologi Tindak Pidana Korupsi di Indonesia. Mandar Maju, Bandung. 2017. Hal 28.
}

DOI: https://doi.org/10.30598/belovol6issue1page1-10 
Nomor 2 Tahun 2020. Sifat melawan hukum (wederrechtelijkheid) merupakan unsur yang sangat penting dalam hukum pidana. ${ }^{5}$ Sifat melawan hukum sangat berhubungan dengan penegakan hukum nantinya. ${ }^{6}$ Apalagi sifat melawan hukum materiil akan berhubungan erat sekali dengan rasa keadilan masyarakat. ${ }^{7}$ Metode yang dipakai adalah yuridis normatif dengan pendekatan peraturan perundang-undagan dan pendekatan konsep. Analisis kualitatif dengan memakai bahan hukum primer, sekunder dan tersier.

\section{Pembahasan}

Pemeritah mengelontorkan dana $\mathrm{Rp} 405,1$ triliun, lalu naik menjadi $\mathrm{Rp} 677$ triliun, Rp 695,2 triliun, Menteri Keuangan memprediksi dana penagganan covid-19 akan mencapai Rp 905,1 triliun. Dana sebesar ini tentunya akan mengalami masalah dikemudian hari jika tidak dikelola dengan baik. Jika kita melihat beberapa pemberitaan di media cetak dan media elektronik maka ada beberapa dugaan tindak pidana, data yang dikutip bawah sudah 55 Kasus yang sudah ada di Direktorat Tidak Pidana Korupsi yang tersebar di 12 Provinsi, ${ }^{8}$ Korupsi merupakan permasalahan universal yang dihadapi oleh seluruh negara dan masalah pelik yang sulit untuk diberantas, hal ini tidak lain karena masalah korupsi bukan hanya berkaitan dengan permasalahan ekonomi semata, melainkan juga terkait dengan permasalahan politik, kekuasaan dan penegakkan hukum. ${ }^{9}$ Fenomena dugaan penyalahgunaan keuangan negara memang merupakan masalah tersendiri yang muncul dimasa pandemik.

Undang-Undang Nomor 2 Tahun 2020 tentang Penetapan Peraturan Pemerintah Pengganti Undang-Undang Nomor 1 Tahun 2020 tentang Kebijakan Keuangan Negara

\footnotetext{
${ }^{5}$ Roni Wiyanto, Asas-Asas Hukum Pidana Indonesia, CV Mandar Maju, Bandung. 2017. Hal 231
}

${ }^{6}$ Fadillah A. N., Aspary M. I. A. A. (2020). Optimalisasi Penegakan Hukum Pidana Terhadap Tindak Pidana Perikanan (Studi Perbandingan Hukum Pidana Di Bidang Perikanan). Sasi, Volume 26 Nomor 2. Hal 227

${ }^{7}$ Hiariej, E. O. Prinsip-Prinsip Hukum Pidana. Yogyakarta: Cahaya Atma Pustaka. 2016. Hal 13

${ }^{8}$ https://bogor.pikiran-rakyat.com/nasional/pr-08598052/polri-kantongi-55-kasus-dugaan penyelewengan-dana-bansos-covid-19-motifnya-potongan-bantuan, diakses 17 Juli 2020

${ }^{9}$ Fikry Latukau. (2019). Pengadopsian UNCAC Mengenai Pengembalian Aset Hasil Korupsi Yang Dibawa Atau Disimpan Ke Luar Negeri Dalam Penegakan Hukum Indonesia, Jurnal Belo, Volume 5 Nomor 1. Hal 10 
dan Stabilitas Sistem Keuangan untuk Penanganan Pandemi Corona Virus Disease 2019 (Covid-19) dan/atau Dalam Rangka Menghadapi Ancaman Yang Membahayakan Perekonomian Nasional dan/atau Stabilitas Sistem Keuangan Menjadi Undang-Undang. Pasal 27 Undang-Undang Nomor 2 tahun 2020 kembali digugat oleh beberapa lapisan masyakat pasca penetapan Dewan Perwakilan Rakyat, mereka mengangap bahwa Pasal 27 Undang-Undang Nomor 2 Tahun 2020 berbahaya karena menimbulkan hak imunitas terhadap Pemerintah dan/atau lembaga Anggota Komite Stabilitas Sistem Keuangan (KSSK), KSSK terdiri dari Menteri Keuangan, Gubenur Bank Indonesia, Ketua Dewan Komisioner Otoritas Jasa Keuangan, Ketua Dewan Komisioner Otoritas Lembaga Penjamin Simpanan.

Sebelum membahas tentang sifat melawan hukum, penulis menjelaskan tentang Pasal 27 :

ayat 1 : Biaya yang telah dikeluarkan Pemerintah dan/atau lembaga anggota KSSK dalam rangka pelaksanaan kebijakan pendapatan negara termasuk kebijakan di bidang perpajakan, kebijakan belanja negara termasuk kebijakan di bidang keuangan daerah, kebijakan pembiayaan, kebijakan stabilitas sistem keuangan, dan program pemulihan ekonomi nasional, merupakan bagian dari biaya ekonomi untuk penyelamatan perekonomian dari krisis dan bukan merupakan kerugian negara.

ayat 2 : Anggota KSSK, Sekretaris KSSK, anggota sekretariat KSSK, dan pejabat atau pegawai KementerianKeuangan, Bank Indonesia, Otoritas Jasa Keuangan, serta Lembaga Penjamin Simpanan, dan pejabat lainnya, yang berkaitan dengan pelaksanaan Peraturan Pemerintah Pengganti Undang-Undang ini, tidak dapat dituntut baik secara perdata maupun pidana jika dalam melaksanakan tugas didasarkan pada iktikad baik dan sesuai dengan ketentuan 
peraturan perundang-undangan.

Ayat 3 : Segala tindakan termasuk keputusan yang diambil berdasarkan Peraturan Pemerintah Pengganti Undang- Undang ini bukan merupakan objek gugatan yang dapat diajukan kepada peradilan tata usaha negara.

Pasal ini berhubungan dengan Pasal 2 ayat 1 dan Pasal 3 Undang-Undang Nomor 31 Tahun 1999 tentang Pemberantasan Tindak Pidana Korupsi yang mengatur soal kerugian Negara dan perbuatan korupsi pada saat masa penangganan bencana, di dalam Putusan Mahkamah Konstitusi Nomor 25/PUU-XIV/2016, merubah pasal 2 ayat 1 dan Pasal 3, menghilangkan frasa "dapat" sehingga kerugiaan Negara berubah dari kerugian potensial ke fakta telah terjadi kerugian neraga, jadi harus ada kerugian Negara yang telah terjadi akibat perbuatan dari terdakwa baru unsur kerugian Negara bisa terpenuhi. ${ }^{10}$ Namun bila dikemudian haris sudah terjadi kerugian Negara akibat perbuatan selama penangganan covid-19 oleh pemerintah dan KSSK tidak dapat dimintai pertangungjawaban pidana karena Pasal 27 ayat (1) perbuatan yang mengakibatkan kerugian Negara bukan kerugian Negara.

Penulis berbeda dengan pendapat yang mengatakan pasal 27 mengadung imunitas karena menurut penulis, Pasal 27 mengandung sifat melawan hukum materiil, kita mengetahui bahwa ada dua sifat melawan hukum yaitu sifat melawan hukum formil dan sifat melawan hukum materiil. Ajaran sifat melawan hukum materiil berpandangan bahwa sifat melawan hukumnya suatu perbuatan tidak hanya didasarkan pada peraturan tertulis saja atau hukum tertulis, tetapi juga didasarkan pada asas-asas hukum yang tidak tertulis, itu berarti perbuatan yang bertentangan dengan nilai-nilai yang hidup didalam masyarakat yaitu, kesusilaan, nilai kepatuhan, nilai moral, dan nilai agama.

${ }^{10}$ Erwin Ubwarin, Yonna Beatrix Salamor. (2007). Mekanisme Pengembalian Kerugian Negara oleh Terpidana yang Meninggal Dunia Pasca Putusan Mahkamah Konstitusi Nomor 25/PUU-XIV/2016, Jurnal Muara Ilmu Sosial, Humaniora, dan Seni, Volume 1 Nomor 1, hal 53

DOI: https://doi.org/10.30598/belovol6issue1page1-10 Copyright (c) 2020 Author 
Pasal 27 harus dilihat secara keseluruhan ayat (1) sangat berhubungan dengan ayat (2).

Pasal 27 ayat 2 Peraturan Pemerintah Penganti Undang-Undang Nomor 1 Tahun 2020 adalah mengingatkan pengabil kebijkan agar tetap menggunakan itikhad baik dan sesuai dengan peraturan perundang-undangan agar tidak dituntut pidana. Melawan hukum materiil dalam penagganan bencana alam penting diterapkan untuk rasa keadilan walaupun ada Putusan Mahkamah Konstitusi No. 003/PUU-IV/2006. Hal ini sejalan dengan Putusan Hoge Raad tentang Tukang Kacamata, Namun Jika perbuatan untuk keselamatan, kesejahteraan dan kepentingan masyarakat banyak, tentunya tidak memenuhi melawan hukum materiil dalam fungsi negatif, dan bila ada perbuatan hukum pidana yang tidak diatur undang-undang namun melawan hukum materiil dalam fungsi positif. $^{11}$

Melawan hukum materiil adalah menjaga agar rasa keadilan itu tetap ada bukan hanya corong undang-undang semata, walaupun sudah ada Putusan Mahkamah Konstitusi sudah melakukan amputasi tehadap sifat melawan hukum materiil, namun dalam praktek peradilan pidana, masih ada hakim yang memutuskan suatu perkara pidana tindak pidana korupsi dengan menerapkan melawan hukum materiil. Hakim bebas untuk menjatuhkan sebuah putusan, dalam kebijakan hukum pidana ada salah satu kebijakan aplikatif, ${ }^{12}$ hakim melakukan penemuan hukum, mecari dan mengali hukum yang berada di masyarakat (living law), hakim tidak boleh sebagai corong undang-undang.

Walaupun Pasal 27 ayat (1) mengatakan bahwa bukan kerugian Negara, namun jika terbukti telah jadi kerugian Negara, maka hakim harus menjatuhkan pidana terhadap perbuatan tindak pidana korupsi selama masa pandemik Covid-19. Jika kita melihat Pasal 27 ayat (2), disitu pembuat undang-undang sudah mengingatkan pemerintah dan KSSK untuk dalam perbuatannya dalam menanggulangi Covid-19 harus " ada iktikad baik dan

\footnotetext{
${ }^{11}$ Erwin Ubwarin, Patrick Corputty. (2020). Pertangungjawaban Pidana Dalam Keadaan Darurat Bencana Covid-19, Mizan: Jurnal Ilmu Hukum, Volume 9 Nomor 1 . Hal 6

${ }^{12}$ Leonie Lokollo, Yonna Beatrix Salamor, Erwin Ubwarin. (2020). Kebijakan Formulasi Undangundang Narkotika Dalam Legalisasi Penggunaan Ganja Sebagai Bahan Pengobatan di Indonesia. Jurnal Belo, Volume 5 Nomor 2. Hal 3
} 
sesuai dengan ketentuan peraturan perundang-undangan" kalimat ini menunjukan bahwa pembuat undang-undang telah memperingati agar tidak berbuat melawan hukum materiil. Jika perbuata itu baik lakukan walau ada kerugian Negara, namun jika untuk keuntungan sendiri, orang lain atau kelompok, maka sesuai dengan Pasal 2 ayat 2 Undang-Undang Nomor 31 Tahun 1999, Korupsi pada saat Negara sedang mengalami bencana alam adalah hukuman mati.

\section{Penutup}

Sifat melawan hukum materiil adalah sifat melawan hukum untuk menjaga rasa keadilan dalam masyarakat, dana yang begitu besar dalam penaganan covid-19 dapat menimbulkan kerugian Negara jika tidak dipergunakan secara baik, walaupun ada Pasal 27 Undang-undang Nomor 2 Tahun 2020 yang melindungi pemerintah dan KSSK, menurut penulis demi menjaga rasa keadilan, jika perbuatan tersebut merugikan Negara, dan tidak ada manfaatnya kepada pemerintah walaupun Undang-undang melakukan pengucalian perbuatan, tetapi hakim tetap harus membuat torobosan hukum dengan menjatuhkan pidana.

\section{Daftar Pustaka}

\section{Jurnal}

[1] Latukau, F. (2020). Pengadopsian UNCAC Mengenai Pengembalian Aset Hasil Korupsi Yang Dibawa Atau Disimpan Ke Luar Negeri Dalam Penegakan Hukum Indonesia. Jurnal Belo, Volume 5 Nomor 1. DOI: https://doi.org/10.30598/belovol5issue1page10-31

[2] Lokollo, L., Salamor, Y. B., \& Ubwarin, E. (2020). Kebijakan Formulasi Undang-undang Narkotika Dalam Legalisasi Penggunaan Ganja Sebagai BahanPengobatan di Indonesia. Jurnal Belo, Volume 5 Nomor 2. DOI: https://doi.org/10.30598/belovol5issue2page1-20

[3] Mawati, E., Takariawan, A., \& Sulistiani, L. (2020). Kebijakan Hukum Pidana Mengenai Rehabilitasi Psikososial Korban Tindak Pidana Terorisme Dalam 
Sistem Peradilan Pidana. Jurnal Belo, Volume 5, Nomor 2, 34-56. DOI : https://doi.org/10.30598/belovol5issue2page34-56

[4] Susilo, A. (2020). Coronavirus Disease 2019: Tinjauan Literatur Terkini. Jurnal Penyakit Dalam Indonesia, Universitas Indonesia, Volume 7 Nomor 1, Hal 45. DOI : https://doi.org/10.7454/jpdi.v7i1.415

[5] Ubwarin, E., \& Corputty, P. (2020). Pertangungjawaban Pidana Dalam Keadaan Darurat Bencana Covid-19. Mizan: Jurnal Ilmu Hukum , Volume 9 Nomor 1. Hal 6. DOI : $\underline{\text { https://doi.org/10.32503/mizan.v9i1.1043 }}$

[6] Ubwarin, E., \& Salamor, Y. B. (2017). Mekanisme Pengembalian Kerugian Negara oleh Terpidana yang Meninggal Dunia Pasca Putusan Mahkamah Konstitusi Nomor 25/PUU-XIV/2016. Jurnal Muara Ilmu Sosial, Humaniora, dan Seni ,Volume 2 Nomor 1. 51-57 DOI : https://doi.org/10.24912/jmishumsen.v1i1.334

[7] Fadillah A. N., 'M. I. A. A. (2020). Optimalisasi Penegakan Hukum Pidana Terhadap Tindak Pidana Perikanan (Studi Perbandingan Hukum Pidana Di Bidang Perikanan). Sasi, Volume 26 Nomor 2. DOI : https://doi.org/10.47268/sasi.v26i2.280

\section{Buku}

[8] Ermansjah Djajah, (2017) Tipologi Tindak Pidana Korupsi di Indonesia. Bandung Mandar Maju.

[9] Hiariej, E. O. (2016). Prinsip-Prinsip Hukum Pidana. Yogyakarta: Cahaya Atma Pustaka.

[10] Roni Wiyanto, (2017) Asas-Asas Hukum Pidana Indonesia, Bandung. CV Mandar Maju.

\section{Lain-lain}

[11] https://www.cnnindonesia.com/ekonomi/20200619172653-532-515291/srimulyani-sebut-dana-penanganan-corona-naik-jadi-rp905-t, diakses 16 Juli 2020 
[12] https://bogor.pikiran-rakyat.com/nasional/pr-08598052/polri-kantongi-55-kasusdugaan-penyelewengan-dana-bansos-covid-19-motifnya-potongan-bantuan , diakses 16 Juli 2020

DOI: https://doi.org/10.30598/belovol6issue1page1-10 